\title{
Protagonismo Infantil / Children's Protagonism
}

https://doi.org/10.21814/uminho.ed.36.52

\section{Manfred Liebel}

Technical University Berlin; co-founder and patron of the Master in Childhood Studies and Children's Rights at Free University Berlin and University of Applied Sciences Potsdam; consultant of the Movements of Working Children in Latin America and Africa, Germany 



\section{Protagonismo Infantil}

O debate sobre o protagonismo das crianças é comparável ao debate sobre a agência das crianças nos estudos sociais da infância que surgiu, na década de 1980, no Norte Global. No entanto, enquanto a agência é geralmente vista como uma disposição individual para a ação e limitada por condições sociais, o protagonismo é entendido como uma ação coletiva que também é produzida por experiências de vida. 0 último debate situa-se principalmente no Sul Global.

O protagonismo é entendido como a defesa coletiva das crianças contra a exploração e, em geral, contra as condições de vida e o comportamento dos adultos, considerados degradantes e injustos. As crianças esforçam-se por uma vida melhor, na qual sua dignidade humana seja protegida. Parte-se do princípio de que são as próprias crianças que tomam a iniciativa e dão o exemplo aos adultos. Protagonismo, entretanto, não deve ser confundido com vanguardismo, uma vez que não envolve qualquer reivindicação de liderança sobre outras pessoas. Também não é a expressão de um conflito geracional, uma vez que não é dirigido contra os adultos, mas contra as condições estruturais de desigualdade de poder, incluindo aquelas entre adultos e crianças (adultocentrismo, adultismo).

O discurso sobre o protagonismo infantil surgiu no final dos anos 1970 na América Latina. Está ligada ao movimento de educação popular e ao surgimento dos movimentos sociais de crianças e adolescentes trabalhadores, que surgiram a partir da década de 1990 também na África e Ásia. O foco centra-se nas crianças socialmente excluídas e exploradas. 0 discurso do protagonismo infantil parte do conceito de protagonismo popular, referente aos movimentos sociais que lutam ativamente pela libertação e por melhores condições de vida de grupos como as pessoas sem-terra, moradores de bairros pobres das cidades, indígenas e afrodescendentes.

Analiticamente, as formas espontâneas e organizadas de protagonismo infantil podem ser diferenciadas. 0 protagonismo espontâneo manifesta-se sobretudo nas estratégias de sobrevivência de crianças em situações difíceis. 0 caso mais comum é quando as crianças que moram na rua se sustentam. Um tipo espontâneo de protagonismo também se expressa quando 
as crianças se rebelam contra o tratamento injusto em suas casas; quando exigem ser levados a sério e respeitados; quando cuidam da casa e dos seus irmãos ou irmãos mais novos, enquanto as suas mães ou responsáveis são forçados a trabalhar fora de casa; quando eles resistem a serem forçados a trabalhar contra a sua vontade.

A forma organizada de protagonismo é observada quando as crianças estabelecem uma relação solidária para poder concretizar os seus interesses e exigir os seus direitos. Os movimentos sociais infantis representam uma forma ideal de protagonismo organizado. Eles são dirigidos pelas próprias crianças, permitindo a participação significativa das crianças, independentemente da sua origem, sexo, idade ou cor de pele; em vez disso, o protagonismo torna-se uma realidade por meio de relações de respeito e apoio mútuo.

Quais são as condições precedentes que levam ao surgimento e desenvolvimento mais fácil do protagonismo? Alguns respondem a esta pergunta afirmando que o protagonismo das crianças é o resultado da intervenção educacional. Outros atribuem ao trabalho educativo um importante papel de apoio, mas consideram, acima de tudo, os pressupostos de protagonismo dados pelas próprias crianças. Nesse sentido, as raízes do protagonismo infantil estão baseadas na sua realidade e nas suas vivências quotidianas. Isso pressupõe que as crianças lidem e interpretem a sua realidade à sua maneira, mesmo quando não podem ou não gostariam de articulá-la de uma forma compreendida pelos adultos. Para compreender o protagonismo infantil, devem ser levadas em consideração as suas condições antropológicas, culturais e sociais. Estes criam e mudam processos históricos e não são iguais para todas as sociedades ou para todas as crianças. Refiro-me aqui a quatro suposições.

Em primeiro lugar, as crianças podem ser consideradas descobridoras do mundo desde o momento do nascimento. Desde que nascem, expressam desejos e se articulam como seres humanos com necessidades. Logo, começam a enfrentar o mundo e a descobri-lo com curiosidade e prazer. Em segundo lugar, pode-se supor que as crianças respondem à exclusão e negação da sua subjetividade e dignidade unindo-se espontaneamente a outras crianças e descobrindo interesses comuns. Desta forma, estabelecem amizades e alianças, para serem protegidas em caso de perigo ou para obterem a subsistência diária. Em terceiro lugar, pode-se supor que o protagonismo das crianças resulta da erosão das funções e da autoridade dos adultos nas instituições tradicionais dedicadas à educação e ao controlo 
social das crianças, em particular da família e da escola. Além disso, as crianças adaptam-se com mais flexibilidade às mudanças tecnológicas e sociais e adotam, de forma mais inovadora, os conhecimentos necessários para se orientar e se posicionar num mundo em mudança. Em quarto lugar, no caso de crianças trabalhadoras, o protagonismo pode ser traçado pela sua experiência de trabalho. Dá-lhes uma independência antecipada, não apenas no sentido de que podem ter dinheiro para gastar, mas também porque têm a oportunidade de se sentirem capazes e produtivas. Desta forma, também contribuem para a abolição das subordinações paternalistas, baseadas exclusivamente na menoridade.

O protagonismo das crianças não é um resultado automático das condições nomeadas. Outros elementos são necessários para que ela seja expressa. Particular importância têm os espaços sociais, onde as crianças podem comunicar e expressar-se livremente. Tais espaços são oferecidos, por exemplo, por projetos de educação popular ou movimentos sociais de crianças trabalhadoras. 0 coprotagonismo dos adultos é sempre necessário, no sentido destes darem o exemplo e se comprometerem com uma vida mais justa e respeitosa, também em relação aos filhos.

\section{Children's Protagonism}

The debate on children's protagonism is comparable to the debate on children's agency in social childhood studies that emerged in the 1980s in the Global North. However, while agency is usually seen as an individual inclination to action and limited by social conditions, protagonism is understood as collective action that is produced also by lived experiences. The latter debate is situated mainly in the Global South.

Protagonism is understood as children's collective defence against exploitation and generally, against living conditions and the behaviour of adults, which are perceived as degrading and unjust. The children strive for a better life in which their human dignity is safeguarded. It is assumed that children themselves take the initiative and set an example to adults. Protagonism, however, should not be confused with avant-gardism, since it does not involve any claim to leadership over other people. Nor is it an expression of a generational conflict, since it is not directed against adults, but against the structural conditions of power inequality including those between adults and children (adult-centrism, adultism). 
The discourse on children's protagonism emerged in the late 1970s in Latin America. It is linked to the popular education movement and to the rise of the social movements of working children and adolescents, which came into being from the 1990s in parts of Africa and Asia. The focus is centred on socially excluded and exploited children. The discourse on children's protagonism is taken from the concept of popular protagonism, concerning social movements that actively fight for liberation and for the improved living conditions of population groups such as people without land, inhabitants of poor neighbourhoods in the cities, or indigenous and afro-descent minorities.

Analytically, spontaneous and organized forms of children's protagonism can be differentiated. Spontaneous protagonism is manifested above all in the survival strategies by children in difficult life situations. The most common case is when the children who live on the street support themselves. A spontaneous type of protagonism is also expressed when children rebel against unfair treatment in their homes; when they demand to be taken seriously and to be respected; when they take care of the household and their younger brothers or sisters while their mothers or guardians are forced to work outside the home; when they resist being forced to work.

The organized form of protagonism is observed when children establish a relationship of solidarity to be able to implement their interests and demand their rights. The social movements of children represent an ideal form of organized protagonism. They are directed by children themselves, allowing children's meaningful participation, regardless of their origin, sex, age, or skin colour; instead protagonism becomes a reality through respectful and mutually supportive relations.

Which conditions precede the rise and facilitated development of protagonism? Some answer this question by stating that children's protagonism is the result of educational intervention. Others assign educational work an important supportive role, but consider, above all, the suggestions of protagonism offered by children themselves. In this sense, the roots of children's protagonism are based on their lived reality and their daily experiences. This presupposes that children deal with and interpret their reality in their own way, even when they cannot or would not articulate it in a way understood by adults. To understand children's protagonism, their anthropological, cultural and social conditions must be taken into consideration. These create and change historical processes, and are not the same for all societies, nor for all children. I refer here to four assumptions. 
Firstly, the children can be considered discoverers of the world from the moment of birth. From when they are born, they express desires, and present themselves as human beings with needs. Soon, they begin to face the world and discover it with curiosity and pleasure. Secondly, it can be assumed that children respond to exclusion and the denial of their subjectivity and dignity by uniting spontaneously with other children and discovering common interests. In this way, they establish friendships and alliances to be protected in case of danger, or to obtain daily subsistence. Thirdly, it can be assumed that children's protagonism results from the erosion of adult functions and authority in traditional institutions dedicated to the education and social control of children, in particular of the family and school. Furthermore, children adapt with more flexibility to technological and social changes, and they adopt the necessary knowledge to orient themselves and rise up in a changing world more creatively and with greater innovation. Fourthly, in the case of working children, protagonism can be traced back to their work experience. It gives them earlier independence, not only in the sense that they are allowed to have money to spend, but also because they have the opportunity to feel capable and productive. In this way, they also contribute to the removal of paternalist subordination based exclusively on their status as minors.

Children's protagonism is not an automatic result of the conditions that have been mentioned. Other elements are needed for it to be expressed. Of particular importance are social spaces, where the children can communicate and express themselves freely. Such spaces are offered, for example, by popular education projects or social movements of working children. Co-protagonism by adults is always needed in the sense that they set an example and are committed to a fairer and more respectful way of life, in relation to children as well.

\section{Referências / References}

Cussiánovich, A. (2001). 'What Does Protagonism Mean?' In M. Liebel, B. Overwien \& A. Recknagel (Eds.), Working Children's Protagonism: Social Movements and Empowerment in Latin America, Africa and India (pp. 157-170). Frankfurt/M and London: IKO.

Liebel, M. (2007). Paternalism, Participation and Children's Protagonism. Children, Youth and Environments, 17(3), 56-73.

Taft, J. K. (2015). “Adults talk too much”: Intergenerational dialogue and power in the Peruvian movement of working children'. Childhood, 22(4), 460-473. 